Correction

\title{
Correction: Bastarrachea, L.J., et al. Active Packaging Coatings. Coatings 2015, 5, 771-791
}

Luis J. Bastarrachea, Dana E. Wong, Maxine J. Roman, Zhuangsheng Lin and Julie M. Goddard * Department of Food Science, University of Massachusetts Amherst, 102 Holdsworth Way, Amherst, MA 01003, USA; lbastarr@umd.edu (L.J.B.); dewong@foodsci.umass.edu (D.E.W.);

mjroman@foodsci.umass.edu (M.J.R.); zhuangshengl@foodsci.umass.edu (Z.L.)

* Correspondence: goddard@foodsci.umass.edu; Tel.: +1-413-545-2275; Fax: +1-413-545-1262

Academic Editor: Alessandro Lavacchi

Received: 1 June 2016; Accepted: 6 June 2016; Published: 8 June 2016

The authors wish to make the following correction to this paper [1]:

Reference 116 has been replaced by:

Koontz, J. Active Packaging Materials to Inhibit Lipid Oxidation: US Regulatory Framework.

Int. News Fats Oils Relat. Mater. 2012, 23, 598-600.

The manuscript will be updated and the original will remain available on the article webpage. The authors would like to apologize for any inconvenience caused to the readers.

\section{Reference}

1. Bastarrachea, L.J.; Wong, D.E.; Roman, M.J.; Lin, Z.; Goddard, J.M. Active Packaging Coatings. Coatings 2015, 5, 771-791. [CrossRef]

(C) 2016 by the authors; licensee MDPI, Basel, Switzerland. This article is an open access article distributed under the terms and conditions of the Creative Commons Attribution (CC-BY) license (http://creativecommons.org/licenses/by/4.0/). 